\title{
Review
}

\section{The use of immunization registry-based data in vaccine effectiveness studies}

\author{
Hilary Placzek ${ }^{\mathrm{a}, *}$, Lawrence C. Madoff ${ }^{\mathrm{b}, \mathrm{c}, 1}$ \\ a Clinical and Population Health Research, University of Massachusetts Medical School, 55 Lake Ave North, Worcester, MA 01655-0002, United States \\ ${ }^{\mathrm{b}}$ Division of Epidemiology and Immunization, Massachusetts Department of Public Health, William A. Hinton State Laboratory Institute, 305 South Street, \\ Jamaica Plain, MA 02130, United States \\ ${ }^{\mathrm{c}}$ Department of Medicine, University of Massachusetts Medical School, 55 Lake Avenue North, Worcester, MA 01655-0002, United States
}

\section{A R T I C L E I N F O}

\section{Article history:}

Received 22 July 2010

Received in revised form 13 October 2010

Accepted 1 November 2010

Available online $\mathrm{xxx}$

\section{Keywords:}

Vaccine

Effectiveness

Registry

\begin{abstract}
A B S T R A C T
Vaccine effectiveness (VE) studies provide a measure of population-based vaccine performance by combining immunization history data with rates of disease incidence. This review assessed the feasibility of using electronic immunization registry data sources in VE studies. Electronic databases were searched through January 31, 2010. Out of 17 studies, only one paper assessed data accuracy (71\%), and three papers assessed population coverage of the registry (estimates ranged from $25 \%$ to $90 \%$ ). This review shows that registry-based data sources can be used to conduct VE studies in a variety of settings and populations. However, we found little information regarding the quality of this data source in VE studies and future evaluations should investigate their reliability, accuracy, and potential bias.
\end{abstract}

(c) 2010 Elsevier Ltd. All rights reserved.

\section{Contents}

1. Introduction

2. Methods.

2.1. Search strategy ....

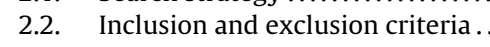

2.3. Definitions......

2.4. Data abstraction.......

2.5. Quality rating scores.

2.6. Analyses ....

3. Results....

3.1. Search results....

$\begin{array}{lll}0 & 0\end{array}$

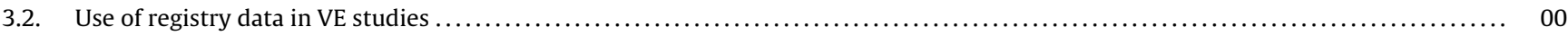

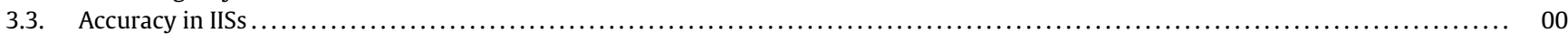

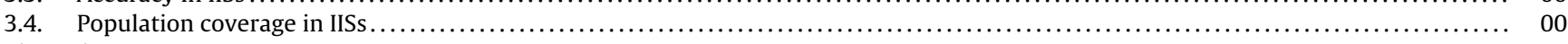

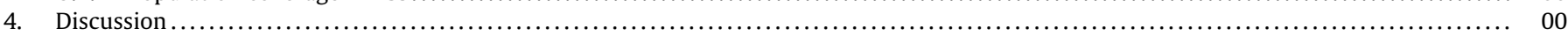

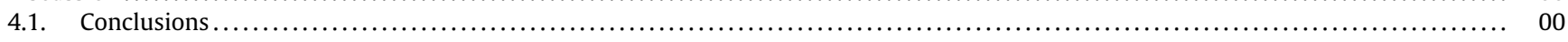

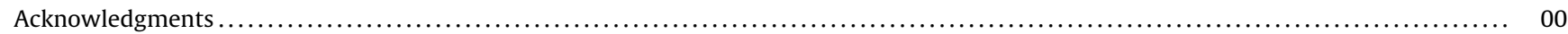

Appendix A. Abstraction form for a systematic review: immunization registry data as a method of surveillance in a pediatric population ........ 00

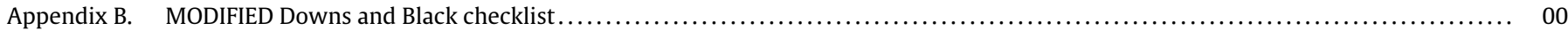

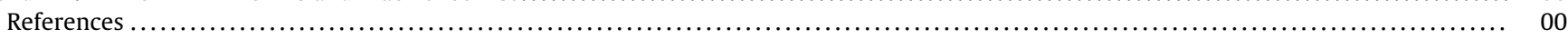

\footnotetext{
* Corresponding author. Tel.: +1 413427 6662; fax: +1 5088563659.

E-mail addresses: hilary.placzek@umassmed.edu, hplaczek@gmail.com (H. Placzek), larry.madoff@state.ma.us (L.C. Madoff).
}

1 Tel.: +1 617983 6803; fax: +1 6179836840 .

\section{Introduction}

In the United States, national recommendations provide guidance for use of vaccines to reduce, eliminate, or eradicate 17 vaccine-preventable diseases. Recent reports indicate that the number of cases of most vaccine-preventable diseases (VPD) is at an all-time low. Hospitalizations and deaths attributable to VPD have also decreased [1]. Other estimates indicate that vaccination

0264-410X/\$ - see front matter @ 2010 Elsevier Ltd. All rights reserved. doi:10.1016/j.vaccine.2010.11.007 
with 7 of the 12 routinely recommended childhood vaccine prevents an estimated 33,000 deaths and 14 million cases of disease in every birth cohort, and saves society an additional $\$ 33$ billion in costs including disability and lost productivity [2].

However, despite their goal of providing safe, effective disease prevention, vaccines do not guarantee complete protection. Recently published literature has re-examined epidemiological concepts surrounding two study designs used to determine how well a vaccine performs [3]. Pre-licensure, experimental vaccine efficacy trials represent how well the vaccine performs under controlled conditions, and are best measured by double-blind, randomized, clinical control trials [4]. This paper will focus on population-based vaccine effectiveness (VE) studies. Evaluations of VE occur after vaccine efficacy has been established, and assess how well a vaccine performs under natural field conditions rather than in a controlled clinical trial. VE studies take into account vaccine potency, how well target groups are immunized, and can control for the complexities of immunization practices and transmission dynamics such as exposure to disease, or individual response to particular vaccines. Measures of VE can also assess the benefits and effects of a vaccination program or identify previously unknown factors related to vaccine failure, and are critical to ensure that a licensed vaccine is working within a population.

Several study designs can be used to evaluate VE: (1) retrospective case control studies compare vaccination rates among infected cases and controls. This type of study expresses VE as a rate difference by calculating an odds ratio (OR) for developing infection despite vaccination; (2) an indirect cohort study examines individual protective responses by comparing vaccine-serotype infection rates with nonserotype-infection rates within a diseased population [5]; (3) case-coverage studies compare vaccination rates among cases with those of a similar cohort over a defined period of time, or (4) observational studies examine the change in disease burden and impact of a vaccine within a population over time [3]. Observational studies are often designed to measure the impact of a vaccine program by studying the effect of disease incidence in a population before and after program implementation [6], and to determine the relative risk of disease among the vaccinated groups compared to the unvaccinated $[7,8]$.

In the U.S., VE studies have utilized population-based data by measuring immunization rates by telephone surveys, schooland practice-based assessments, and insurance claims information, among others. These methods can be time-consuming, expensive, and biased [9]. In response, an increasing number of resources, including immunization registries, maintain immunization records for infants, children, adolescents, and adults. These immunization information systems (IISs) are repositories of immunization data within specified geographic areas. IISs collect and consolidate records of vaccinations from multiple health care providers and across care settings. These surveillance systems have been shown to provide better immunization delivery by assisting in medical decision-making, reminder recall, determining coverage levels, and identifying pockets of need [10-15]. IISs can be used in VE studies to measure the degree of vaccine uptake in a variety of settings and populations by identifying confirmed VPD cases and/or confirming immunization history. Investigators then use this information to calculate vaccine performance [16-19].

Using IIS data can offer several methodological advantages over traditional observational studies. First, registries may allow more rigorous research methods to be used: in population-based studies, IISs provide individual-level information that can be matched with VPD morbidity data and could be used to conduct large cohort studies more efficiently. One benefit of cohort studies is that they are less prone to bias than case-control studies, a widely used design in populations lacking registries. In case-control studies, IISs can also provide a uniform method of determining vaccination status for cases or controls, and can reduce bias due to differential ascertainment of vaccination status. VE studies using IIS data can use case-control or population-based study designs such as prospective or retrospective cohort, or cross-sectional study design. Since registries contain population-based data for large numbers of people, extracting immunization information from a registry means that cohort studies could be conducted in populations with low incidence of disease, or in other low-risk populations since there is a larger sample from which to draw [20]. In addition, centralized data sources can allow researchers to measure the impact of vaccination in populations precisely by defining the base population more clearly. This population-based approach can prevent the introduction of socioeconomic or demographic biases that may be present in other data sources such as HMO-based data [21].

There is also evidence that the use of registry-based data is a developing field. Many immunization registries are currently operating all over the world. The US government, through CDC goals of expanding registries and financial incentives for fulfilling meaningful use objectives for electronic health records (EHRs), is instrumental in the promotion of IISs [22]. Furthermore, the Health Information Technology for Economic and Clinical Health Act (HITECH) Provisions within the ARRA were enacted in February 2009 [23]. As a result, there is an emphasis on improving health information technology in the US, and an increasing number of registries at state, city, and regional levels [12,24]. Centralized statewide registries are currently operating in 48 of 50 states, as well as several cities $[21,25,26]$. In one recent study, IIS data from eight states and one city (representing approximately $10 \%$ of the U.S. population) was used in the Post-Licensure Rapid Immunization Safety Monitoring (PRISM) study identifying adverse events from the H1N1 vaccine. PRISM represents a novel way of linking IISs and heath plan data to assess population-based immunization coverage and outcomes data on a nationwide basis.

However, considerable gaps exist in the literature detailing precisely how registries can facilitate more accurate, population-based vaccine effectiveness studies. In addition, harnessing IISs is a new and expanding field, and methodological limitations such as missing, inaccurate, or the potential for biased data have not been fully explored. Observational studies of vaccine effectiveness at the population level depend on accurate data [27], and recent studies have found that vaccination studies relying on electronic records may misclassify vaccinated individuals as unvaccinated, thereby producing inaccurate estimates of vaccine effectiveness [28]. This systematic review will determine how registries have been used to conduct VE studies, and if data contained in the registry is accurate and generalizable through the following aims: (1) to assess if an individualized, centralized system for tracking immunization rates can be utilized in vaccine effectiveness studies, (2) to describe reported estimates and methods to measure accuracy of registry data in VE studies, and (3) to describe reported results and methods to measure base population coverage of registry data in VE studies.

\section{Methods}

We conducted a systematic review of all available medical literature through January 31, 2010 that referred to or established the use of registry-based data sources to evaluate vaccine effectiveness.

\subsection{Search strategy}

We searched the electronic databases PubMed, MedLine, EMBASE, MeSH, ISI Web of Science, and the CDC immunization information system (IIS) Database. The following terms were used: 'registry-based vaccine effectiveness', or key words 'immunization registry or register and vaccine effectiveness'; 
'immunization information system and vaccine effectiveness' (PubMed; MedLine; EMBASE); 'vaccination registry'; or 'coverage'; or 'registries/standards'; or 'registries/statistics and numerical data'; or 'vaccination/statistics and numerical data'; or 'immunization programs/standards'; or 'immunization programs/statistics and numerical data' (MeSH); 'vaccin*; registr* and effective*' (ISI Web of Science); and 'vaccination registry' (CDC IIS search). This strategy was supplemented by searching the reference lists of included articles to identify additional papers. Two authors of included studies provided supplemental materials; and two authors were contacted for recently published article content that was not available during the initial search attempt.

\subsection{Inclusion and exclusion criteria}

Inclusion criteria were as follows: (1) researchers extracted registry-based immunization data to conduct vaccine effectiveness study in a human population; (2) study utilized any population-based, centralized (national, statewide, countywide, etc.) immunization registry data as a main source of vaccination status information; and (3) studies were published in English.

Exclusion criteria were as follows: (1) review papers; (2) studies published in a language other than English; (3) studies that included HMO-based or hospital-registry-based data only, without population-based data; (4) studies that did not address vaccine effectiveness; (5) studies with poor quality rating scores defined as $<7$ points out of a possible 14 points.

\subsection{Definitions}

'Registry-based' was defined as any population-based data source maintained at the local, regional, or national level that systematically collects immunization history information. Institutional- or HMO-based data did not meet review criteria in this context. The 'reference data source' refers to a demographic, census, or other population-based data source researchers used to validate population-based registry data utilized in the study (if applicable). 'Population coverage estimates' are the reported percentage of the source population included in the IIS. 'Accuracy' reported is the percentage of data that was consistent between the registry information and a validated measure (i.e. provider records, parent recall, or manual validation). In addition, 'VPD data sources' are the data sources used to provide a measure of VPD to calculate rates of vaccine effectiveness.

\subsection{Data abstraction}

We conducted a preliminary review by scanning article titles and abstracts; papers were then retrieved, and study text was scanned to determine if all inclusion criteria were met. To systematically collect data from included studies, we developed a data abstraction form that was pilot-tested prior to data collection (Appendix A).

\subsection{Quality rating scores}

A modified Downs and Black quality rating scale was used to rate the studies (Appendix B) [29]. We modified some text of the checklist and removed questions related to randomized case-control and intervention studies since these were not appropriate in this context. We then abstracted data from the selected papers, rated the studies independently, and compared our quality rating scores. Discrepancies in quality rating were discussed and addressed to reach study quality consensus between reviewers.

\subsection{Analyses}

We determined the number of studies using registry-based data to conduct VE studies. We then determined the distribution of rates for population coverage estimates, reported accuracy, and described this range using descriptive statistics.

\section{Results}

\subsection{Search results}

Two hundred ninety-three papers were identified as fulfilling the initial search criteria.

After application of the inclusion and exclusion criteria, 280 of the studies were discarded (Fig. 1), and we included 13 articles for final review. The main reason for exclusion was that the study did not use registry-based data to calculate VE (137 papers, $49 \%$ of excluded studies). No studies were dropped because of poor study quality.

Through direct systematic personal communication with included authors, we obtained four additional papers and included them in the final review.

Table 1 describes basic characteristics of included articles. The year of publication ranged from 1997 to 2010, and 13 of the 17 papers (76\%) were published during or after 2004. Included studies utilized four types of study design, and occurred in nine countries focusing on ten vaccine-preventable diseases. Registry types included citywide, countywide, regional, statewide, and national IIS systems. Studies used VPD data collected from healthcare providers $[30,31]$, linked notification reports systems and hospital discharge diagnosis data [32,33], or other national/regional disease surveillance systems [34]. Information related to matching IIS data with incident disease data at the individual-level is also included.

Table 2 contains information from the included studies highlighting specific IIS details. Results of the modified Downs and Black checklist to assess study quality indicate that out of a possible fourteen points, all included studies scored at least 7 points, with a mean study score of 11 , and a range from 7 to 14 points. This table also lists population-based data sources used for reference purposes, study contexts, as well as accuracy and source population coverage rates.

\subsection{Use of registry data in VE studies}

Reviewed VE studies demonstrated three unique contexts in which registry-based data sources could identify immunization history data:

1. Responding to an outbreak: Three studies responded to epidemiological data showing an alarming increase in incidence for a particular type of vaccine-preventable disease. These studies used IIS-based data to identify outbreak cases and determine immunization history of these cases. Studies were retrospective in nature $[30,31,35]$.

2. Assess how vaccination affects incidence of disease: Eight studies sought to measure the impact of vaccination programs by comparing population-based immunization data with incident rates of disease before and after implementation of vaccine programs. Study results were reported as changes in rates of incident disease as a result of implementation of vaccination or another intervention. Studies were retrospective if authors assessed or evaluated a vaccine program following its implementation [6,36-40]. One paper prospectively monitored the impact of a vaccine intervention at the beginning of program implementation [8]. 


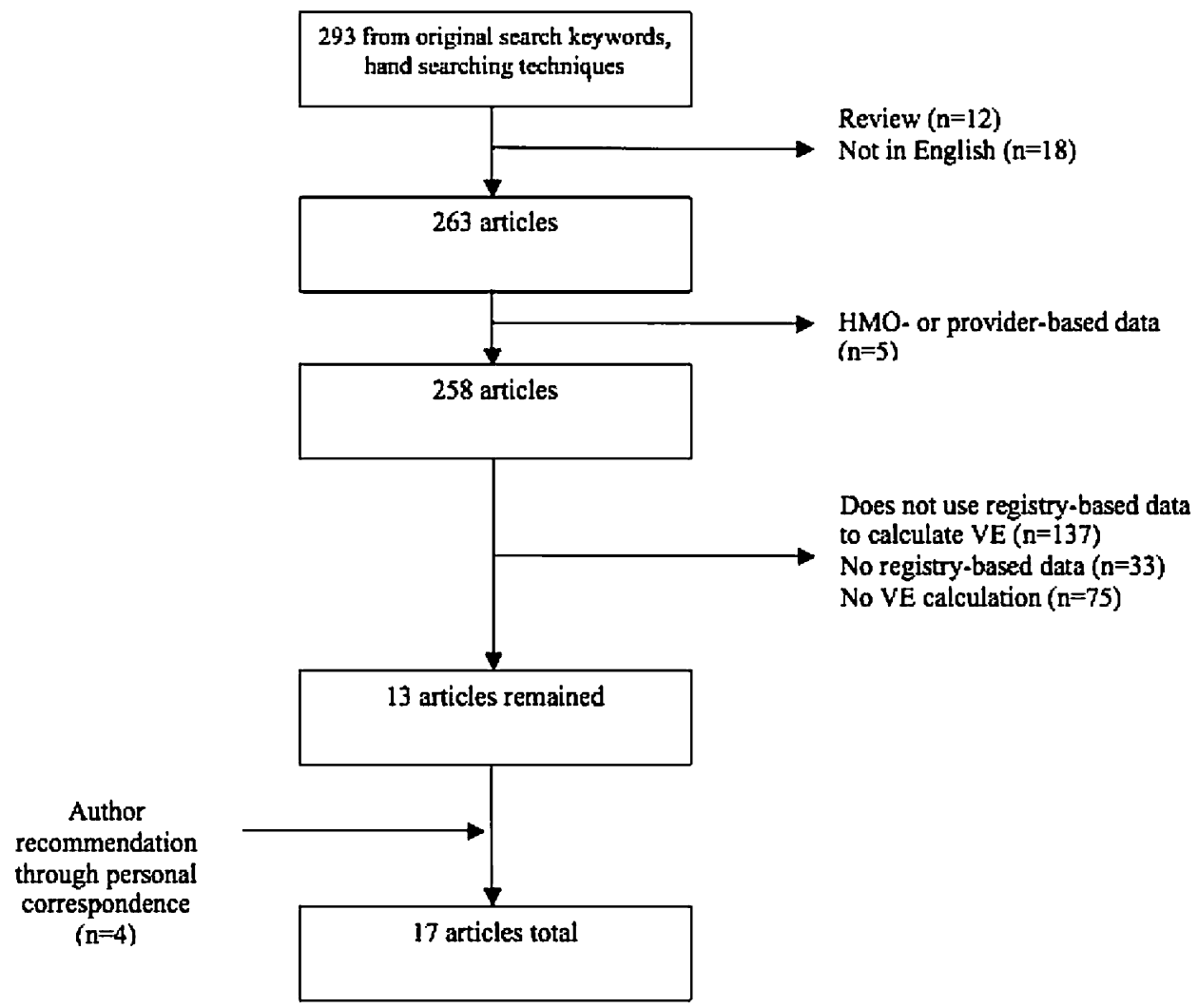

Fig. 1. Flow chart of included and excluded articles.

3. Estimate vaccine effectiveness for a specific vaccine using population-based data: Six studies monitored how effectively vaccines could prevent VPD. Of these, two studies matched cases with controls to conduct case-control evaluations of VE [41,42]. Three studies utilized a population-based data source to calculate risks of infection in vaccinated compared to unvaccinated groups, and expressed VE as an odds ratio (OR) [19,33,34]. One paper conducted serological testing of possible influenza cases, and compared vaccination rates between laboratory-confirmed and-unconfirmed cases [12]. In these studies, authors calculated VE by comparing immunization history data with incident cases of disease.

\subsection{Accuracy in IISs}

Only one of the 17 papers (6\%) addressed accuracy of information contained in the IIS (Table 2). In this study, researchers found $65-77 \%$ accuracy of IIS data.

In this instance, Boom et al. assessed the effectiveness of pentavalent rotavirus vaccine (RV5). They also sought to validate immunization data from the Houston-Harris County Immunization Registry (HHCIR) against provider records to assess the utility of an IIS in evaluating VE. Results showed that registry data were the same as the provider record for $71 \%$ of patients. These authors also found that VE calculated using IIS data (VE for RV5 was $89 \%$ [CI]:70-96\% and 85\% [CI]:55-95\%) was similar to estimates using a manually validated control group based on provider records $(82 \%$ [CI]: 19-96\%) [42].

\subsection{Population coverage in IISs}

While there are different methods of comparing or defining a base population, of the 17 papers included in this review, only three
(18\%) reported how many of the source population were included in the registry. Population coverage estimates encompassed a wide range of target population coverage estimates ranging from $25 \%$ to $90 \%$.

For example, $\mathrm{Fu}$ et al. determined the effectiveness of the mumps vaccine against clinical mumps in outbreak cases. Cases were identified from physician-based surveillance data, and only cases whose information was found in the IIS were included in the study. Of the 1849 children in Guangzhou identified with mumps between Sept 1, 2004 and March 31, 2005, 1380 (74.6\% of the total) were excluded because their records were not found in the system [35].

\section{Discussion}

This review shows that registry-based data have been used to evaluate VE in a variety of settings, contexts, and populations. We have found studies that matched registry-based immunization history data and measures of incident disease to assess VE in population-based settings. In order for IISs to provide accurate calculations of VE, however, two major assumptions should be satisfied:

Assumption 1: Data contained in the IIS accurately report who has or has not received a vaccine. This assumes that all IIS information is correct, and requires validation of accuracy, or matching of information from a reference data source. In this review, some papers indicated a need for establishing more accurate data, but did not conduct data validation [36]. Authors also noted that their registry data source might have underestimated current coverage due to incomplete reporting of vaccination status which may cause an underestimation of VE [19].

Assumption 2: Immunization data contained in the registry are representative of the general population. This assumes that the IIS in 
Table 1

Basic characteristics of articles included in the review $(n=17)$.

\begin{tabular}{|c|c|c|c|c|c|c|c|c|c|c|}
\hline & First author & Title & Year & Study design & Vaccine type & Sample size & Study setting & IIS type & VPD data source & $\begin{array}{l}\text { IIS data matched to } \\
\text { individual-level }^{\mathrm{a}}\end{array}$ \\
\hline 1 & Van Alphen & $\begin{array}{l}\text { Effect of nationwide vaccination of } \\
\text { 3-month-old infants in the Netherlands with } \\
\text { conjugate Haemophilus influenzae type b } \\
\text { vaccine: high efficacy and lack of herd } \\
\text { immunity }\end{array}$ & 1997 & Case-control & $\begin{array}{l}\text { Haemophilus } \\
\text { influenzae type b }\end{array}$ & 1.6 million & Netherlands & National & $\begin{array}{l}\text { National Reference Lab for } \\
\text { Bacterial Meningitis }\end{array}$ & Yes \\
\hline 2 & Anonymous & $\begin{array}{l}\text { Measles outbreak - Netherlands, April } \\
\text { 1999-January } 2000\end{array}$ & 2000 & $\begin{array}{l}\text { Retrospective } \\
\text { cohort }\end{array}$ & Measles & 2,907 & Netherlands & National & $\begin{array}{l}\text { National routine } \\
\text { surveillance data }\end{array}$ & Yes \\
\hline 3 & Markey & $\begin{array}{l}\text { The effectiveness of Haemophilus influenzae } \\
\text { type b conjugate vaccines in a high risk } \\
\text { population measured using immunization } \\
\text { register data }\end{array}$ & 2001 & $\begin{array}{l}\text { Retrospective } \\
\text { cohort }\end{array}$ & $\begin{array}{l}\text { Haemophilus } \\
\text { influenzae type b }\end{array}$ & 119 & Australia & National & $\begin{array}{l}\text { Regional Hospital } \\
\text { laboratory/Infection } \\
\text { Control data }\end{array}$ & $\mathrm{N} / \mathrm{A}$ \\
\hline 4 & Averhoff & $\begin{array}{l}\text { Control of hepatitis A through routine } \\
\text { vaccination of children }\end{array}$ & 2001 & Prospective cohort & $\begin{array}{l}\text { Inactivated } \\
\text { hepatitis A }\end{array}$ & 29,789 & $\begin{array}{l}\text { US: Butte County, } \\
\text { CA }\end{array}$ & Countywide & $\begin{array}{l}\text { Enhanced regional } \\
\text { surveillance }\end{array}$ & Yes \\
\hline 5 & Torvaldsen & $\begin{array}{l}\text { Effectiveness of pertussis vaccination in New } \\
\text { South Wales, Australia } 1996-1998\end{array}$ & 2003 & $\begin{array}{l}\text { Retrospective } \\
\text { cohort }\end{array}$ & Pertussis & 1,278 & $\begin{array}{l}\text { South Wales, } \\
\text { Australia }\end{array}$ & National & $\begin{array}{l}\text { Notifiable Diseases } \\
\text { Database of the NSW DoH }\end{array}$ & Yes \\
\hline 6 & Hviid & $\begin{array}{l}\text { Impact of routine vaccination with a conjugate } \\
\text { Haemophilus influenzae type b vaccine }\end{array}$ & 2004 & $\begin{array}{l}\text { Retrospective } \\
\text { cohort }\end{array}$ & $\begin{array}{l}\text { Haemophilus } \\
\text { influenzae type b }\end{array}$ & 758,988 & Denmark & National & $\begin{array}{l}\text { National Hospital } \\
\text { Discharge Registry }\end{array}$ & Yes \\
\hline 7 & Hviid & $\begin{array}{l}\text { Impact of routine vaccination with a pertussis } \\
\text { toxoid vaccine in Denmark }\end{array}$ & 2004 & $\begin{array}{l}\text { Retrospective } \\
\text { cohort }\end{array}$ & Pertussis & 541,525 & Denmark & National & $\begin{array}{l}\text { National Hospital } \\
\text { Discharge Registry and } \\
\text { national reporting data }\end{array}$ & Yes \\
\hline 8 & Barricarte & $\begin{array}{l}\text { Effectiveness of the 7-valent pneumococcal } \\
\text { conjugate vaccine: a population-based } \\
\text { case-control study }\end{array}$ & 2007 & Case-control & $\begin{array}{l}\text { 7-valent } \\
\text { pneumococcal } \\
\text { conjugate (PCV7) }\end{array}$ & 510 & Navarra, Spain & Regional & $\begin{array}{l}\text { Regional hospital } \\
\text { laboratory data }\end{array}$ & Yes \\
\hline 9 & Kelly & $\begin{array}{l}\text { A Prospective Study of the Effectiveness of the } \\
\text { New Zealand meningococcal B vaccine }\end{array}$ & 2007 & Prospective cohort & Meningococcal B & 1,190 & New Zealand & National & $\begin{array}{l}\text { National surveillance } \\
\text { (EpiSurv) combined with } \\
\text { lab data }\end{array}$ & Yes \\
\hline 10 & Ortqvist & $\begin{array}{l}\text { Influenza vaccination and mortality: } \\
\text { prospective cohort study of the elderly in a } \\
\text { large geographical area }\end{array}$ & 2007 & Prospective cohort & $\begin{array}{l}\text { Trivalent } \\
\text { split-virion } \\
\text { influenza }\end{array}$ & 260,000 & $\begin{array}{l}\text { Stockholm County, } \\
\text { Sweden }\end{array}$ & National & $\begin{array}{l}\text { Weekly surveillance, } \\
\text { Swedish Institute for } \\
\text { Infectious Disease Control }\end{array}$ & Yes \\
\hline 11 & $\mathrm{Fu}$ & $\begin{array}{l}\text { Matched case-control study of effectiveness of } \\
\text { live, attenuated S79 mumps virus vaccine } \\
\text { against clinical mumps }\end{array}$ & 2008 & Case-control & $\begin{array}{l}\text { Live, attenuated } \\
\text { S79 mumps virus }\end{array}$ & 938 & Guangzhou, China & Citywide & $\begin{array}{l}\text { Guangzhou Center for } \\
\text { Disease Control and } \\
\text { Prevention (Guangzhou } \\
\text { CDC) }\end{array}$ & Yes \\
\hline 12 & Anonymous & $\begin{array}{l}\text { Interim within-season estimate of the } \\
\text { effectiveness of trivalent inactivated influenza } \\
\text { vaccine-Marshfield, WI 2007-2008 influenza } \\
\text { season }\end{array}$ & 2008 & Case-control & $\begin{array}{l}\text { Trivalent } \\
\text { inactivated } \\
\text { influenza }\end{array}$ & 616 & US: Marshfield, WI & Regional & $\begin{array}{l}\text { Regional/statewide } \\
\text { laboratory data }\end{array}$ & Yes \\
\hline 13 & Adamkiewicz & $\begin{array}{l}\text { Effectiveness of the 7-valent pneumococcal } \\
\text { vaccine in children with sickle cell disease in } \\
\text { the first decade of life }\end{array}$ & 2008 & $\begin{array}{l}\text { Retrospective } \\
\text { cohort }\end{array}$ & $\begin{array}{l}\text { 7-valent } \\
\text { pneumococcal } \\
\text { conjugate (PCV7) }\end{array}$ & 1,247 & $\begin{array}{l}\text { US: Metro Atlanta, } \\
\text { GA }\end{array}$ & Regional & $\begin{array}{l}\text { Pop-based surveillance } \\
\text { from Georgia Emerging } \\
\text { Infections Program (EIP) }\end{array}$ & Yes \\
\hline 14 & Bialek & $\begin{array}{l}\text { Impact of routine hepatitis B immunization on } \\
\text { the prevalence of Chronic hepatitis B virus } \\
\text { infection in the Marshall Islands and the } \\
\text { Federated States of Micronesia }\end{array}$ & 2009 & $\begin{array}{l}\text { Retrospective } \\
\text { cohort }\end{array}$ & Hepatitis B & 1,171 & Micronesia & National & $\begin{array}{l}\text { Laboratory confirmation } \\
\text { from serosurvey samples }\end{array}$ & $\mathrm{N} / \mathrm{A}$ \\
\hline 15 & $\mathrm{Fu}$ & $\begin{array}{l}\text { Evaluation of live attenuated S79 mumps } \\
\text { vaccine effectiveness in mumps outbreaks: a } \\
\text { matched case-control study }\end{array}$ & 2009 & Case-control & $\begin{array}{l}\text { Live, attenuated } \\
\text { S79 mumps virus }\end{array}$ & 388 & Guangzhou, China & Citywide & $\begin{array}{l}\text { Guangzhou Center for } \\
\text { Disease Control and } \\
\text { Prevention (Guangzhou } \\
\text { CDC) }\end{array}$ & Yes \\
\hline 16 & Galloway & $\begin{array}{l}\text { Use of an observational cohort study to } \\
\text { estimate the effectiveness of the New Zealand } \\
\text { group B meningococcal vaccine in children }\end{array}$ & 2009 & $\begin{array}{l}\text { Retrospective } \\
\text { cohort }\end{array}$ & Meningococcal B & 258,421 & New Zealand & National & $\begin{array}{l}\text { Surveillance data from } \\
\text { Institute of Environmental } \\
\text { Science \& Research }\end{array}$ & Yes \\
\hline 17 & Boom & $\begin{array}{l}\text { Effectiveness of pentavalent rotavirus vaccine } \\
\text { in a large urban population in the United States }\end{array}$ & 2010 & Cross-sectional & $\begin{array}{l}\text { Pentavalent } \\
\text { rotavirus (RV5) }\end{array}$ & 285 & $\begin{array}{l}\text { US: Houston-Harris } \\
\text { County, TX }\end{array}$ & Countywide & $\begin{array}{l}\text { Surveillance data, Texas } \\
\text { Children's Hospital }\end{array}$ & Yes \\
\hline
\end{tabular}

a 'N/A' indicates VPD data not matched to individual-level IIS data. 
Table 2

Key IIS components and study characteristics.

\begin{tabular}{|c|c|c|c|c|c|c|c|}
\hline & First author & Year & Quality rating & Study context & $\begin{array}{l}\text { Accuracy } \\
\text { reported }^{\mathrm{a}}\end{array}$ & $\begin{array}{l}\text { Reference } \\
\text { population-based } \\
\text { data source }\end{array}$ & $\begin{array}{l}\text { Source population } \\
\text { coverage }^{\text {b }}\end{array}$ \\
\hline 1 & Van Alphen & 1997 & 10 & $\begin{array}{l}\text { Monitor incidence } \\
\text { of disease }\end{array}$ & $\mathrm{N} / \mathrm{A}$ & $\begin{array}{l}\text { Central Bureau of } \\
\text { Statistics }\end{array}$ & $\mathrm{N} / \mathrm{A}$ \\
\hline 2 & Anonymous & 2000 & 7 & $\begin{array}{l}\text { Responding to an } \\
\text { outbreak }\end{array}$ & $\mathrm{N} / \mathrm{A}$ & $\mathrm{N} / \mathrm{A}$ & $\mathrm{N} / \mathrm{A}$ \\
\hline 3 & Markey & 2001 & 13 & $\begin{array}{l}\text { Monitor incidence } \\
\text { of disease }\end{array}$ & $\mathrm{N} / \mathrm{A}$ & $\begin{array}{l}\text { Australian Bureau } \\
\text { of Statistics }\end{array}$ & $90 \%$ \\
\hline 4 & Averhoff & 2001 & 12 & $\begin{array}{l}\text { Monitor incidence } \\
\text { of disease }\end{array}$ & $\mathrm{N} / \mathrm{A}$ & $\begin{array}{l}\text { State of CA, Dept. of } \\
\text { Finance, } \\
\text { Demographic } \\
\text { Research Unit }\end{array}$ & N/A \\
\hline 5 & Torvaldsen & 2003 & 14 & VE & $\mathrm{N} / \mathrm{A}$ & $\mathrm{N} / \mathrm{A}$ & $\mathrm{N} / \mathrm{A}$ \\
\hline 6 & Hviid & 2004 & 12 & $\begin{array}{l}\text { Monitor incidence } \\
\text { of disease }\end{array}$ & N/A & $\begin{array}{l}\text { Central } \\
\text { Registration } \\
\text { System }\end{array}$ & N/A \\
\hline 7 & Hviid & 2004 & 14 & $\begin{array}{l}\text { Monitor incidence } \\
\text { of disease }\end{array}$ & $\mathrm{N} / \mathrm{A}$ & $\begin{array}{l}\text { Danish Civil } \\
\text { Registration } \\
\text { System }\end{array}$ & $\mathrm{N} / \mathrm{A}$ \\
\hline 8 & Barricarte & 2007 & 11 & VE & $\mathrm{N} / \mathrm{A}$ & $\mathrm{N} / \mathrm{A}$ & $\mathrm{N} / \mathrm{A}$ \\
\hline 9 & Kelly & 2007 & 13 & $\begin{array}{l}\text { Monitor incidence } \\
\text { of disease }\end{array}$ & $\mathrm{N} / \mathrm{A}$ & $\begin{array}{l}\text { Statistics New } \\
\text { Zealand }\end{array}$ & N/A \\
\hline 10 & Ortqvist & 2007 & 13 & $\mathrm{VE}$ & $\mathrm{N} / \mathrm{A}$ & $\begin{array}{l}\text { Stockholm County } \\
\text { Population Register }\end{array}$ & $\mathrm{N} / \mathrm{A}$ \\
\hline 11 & $\mathrm{Fu}$ & 2008 & 11 & $\begin{array}{l}\text { Responding to an } \\
\text { outbreak }\end{array}$ & $\mathrm{N} / \mathrm{A}$ & $\mathrm{N} / \mathrm{A}$ & $25.4 \%$ \\
\hline 12 & Anonymous & 2008 & 9 & $\mathrm{VE}$ & $\mathrm{N} / \mathrm{A}$ & $\mathrm{N} / \mathrm{A}$ & $\mathrm{N} / \mathrm{A}$ \\
\hline 13 & Adamkiewicz & 2008 & 10 & $\begin{array}{l}\text { Monitor incidence } \\
\text { of disease }\end{array}$ & N/A & $\begin{array}{l}\text { National } \\
\text { Immunization } \\
\text { Survey }\end{array}$ & N/A \\
\hline 14 & Bialek & 2009 & 7 & $\begin{array}{l}\text { Monitor incidence } \\
\text { of disease }\end{array}$ & $\mathrm{N} / \mathrm{A}$ & $\mathrm{N} / \mathrm{A}$ & $\mathrm{N} / \mathrm{A}$ \\
\hline 15 & $\mathrm{Fu}$ & 2009 & 11 & $\begin{array}{l}\text { Responding to an } \\
\text { outbreak }\end{array}$ & $\mathrm{N} / \mathrm{A}$ & $\mathrm{N} / \mathrm{A}$ & $\mathrm{N} / \mathrm{A}$ \\
\hline 16 & Galloway & 2009 & 12 & $\mathrm{VE}$ & $\mathrm{N} / \mathrm{A}$ & $\begin{array}{l}\text { Statistics New } \\
\text { Zealand }\end{array}$ & $\mathrm{N} / \mathrm{A}$ \\
\hline 17 & Boom & 2010 & 13 & VE & $71 \%$ & $\mathrm{~N} / \mathrm{A}$ & $44 \%$ \\
\hline
\end{tabular}

a 'N/A' indicates no reported measure of accuracy in study results.

b ' $N / A$ ' indicates no reported measure of source population coverage in study results.

question is representative of the entire denominator of the source population, and requires validation by comparing IIS data to census results or other population-based data sources.

In countries that have linked census, healthcare utilization, and health outcome data, confirming population coverage is more manageable, for example, by using a unique identification number to link all national registries $[33,38]$. However, in countries without integrated national registries, there are no centralized linked statistical bureaus with demographic, healthcare, and utilization data. Without linkage capabilities, it can be challenging to conduct large population-based VE studies. Reference population data used in U.S. studies included National Immunization Survey data [8], or census data from the State of California [6]. These data sources can be limited by low participation rates and selection bias, and may not provide individual-level information.

Individual-level IIS data provide the level of detail required to conduct rigorous VE studies [43], and most population-based VE studies included in this review provide VPD incidence data linked to individual-level immunization data. However, some authors noted that, because of poor quality registry data, precise rates of vaccine coverage could not be determined [6,36], and two studies calculate VE based on aggregate coverage and/or disease levels. In one paper, authors indicated that poor quality IIS data could not be used to calculate immunization history, therefore mean vaccine coverage statistics were used to determine the denominators for VE calculations, rather than using IIS data directly [36]. Another study used IIS data to generate vaccination rates for the popula- tion, but applied these rates to mean disease levels to conclude that implementation of vaccination had decreased incidence of disease [37].

\subsection{Conclusions}

This is the first systematic review that has assessed the use of registry-based data in vaccine effectiveness studies. This review has shown that central immunization registries can be useful tools for evaluating the impact of immunization programs by measuring VE as a response and preventive measure in a variety of populations, study contexts, and diseases. It also demonstrates the potential utility of an immunization registry to conduct future VE studies and highlights future potential applications of registry-based data.

However, this review found that the quality of information may vary between registries, and much work remains to be done validating the accuracy and precision of immunization registry information. Standards and regulations do exist on issues surrounding costs, access and provider matters, validation methods, technical design considerations, and legal environment [12]. It is also true that other literature has addressed accuracy and generalizability of registry-based data $[20,44,45]$, which indicates that validation methods for registry-based data have been developed and tested. In this review, only one study assessed accuracy of IIS data, and three papers assessed source population coverage rates. Because of the limited information available, IIS data quality, inherent bias, and population coverage can be difficult to assess, and 
drawing conclusions about the impact of validation techniques is difficult.

Studies also defined the base population differently, or had limited access to the base population information due to technological or financial limitations. Thus, even if consistent validation methods have been defined and tested elsewhere, technological or financial limitations can be considerable, and researchers may not have the resources to apply consistent validation measures in their studies.

In addition, reliable estimates of VE depend on accurate measures of disease incidence data, and require validated methods to match disease and immunization history data at the individual-level. This review did not assess the quality of incident disease data, but this should be addressed in future work.

Finally, improvements in the quality of individual-level immunization history data would strengthen VE studies using IISs by providing more precise information about who has or has not received a particular vaccine during a specified time period. These data could allow researchers to understand responses to current vaccines and better prepare for future pandemics. Higher quality individual-level data could also help us monitor the impact of the change of vaccines as well as shifts in VE attributable to other factors such as shifts in prevalent strains of pathogens, or herd immunity in the general population. Responding to today's changing and emerging vaccine-preventable diseases, more attention must be paid to the development of registry-based data sources to conduct population-based vaccine effectiveness studies.

\section{Acknowledgments}

We would like to acknowledge the following individuals: Stephanie Schauer, Diana Bartlett, Laura Pabst, Karen Cullen, and Holly Groom (U.S. CDC IIS Branch); Anne McNicholas (New Zealand Ministry of Health); Leila Sahni (Texas Children's Hospital); Susan Lett (Massachusetts Department of Public Health); Bill Adams (Boston Medical Center). 


\section{Appendix A. Abstraction form for a systematic review: immunization registry data as a method of surveillance in a pediatric} population

Number of the study:

Study title:

First author of the study:

Year of publication:

\section{Inclusion and Exclusion Criteria:}

Is the study being included?

1. Yes

2. No

2. Reason(s) for inclusion/exclusion (check the following items that apply from the inclusion and exclusion criteria): Inclusion Criteria:

1. Focus of the study is vaccine effectiveness in a specified population

2. Study utilizes any population-based, centralized (statewide or citywide) immunization registry data as a main source of vaccination status information

3. Studies were published in English.

\section{Exclusion criteria:}

1. Review papers

2. Study does not include population-based registry-based data.

3. Study does not focus on vaccine effectiveness.

4. Studies published in language other than English

5. Studies have poor quality rating score

Reference:

Study type:
a. Clinical trial
b. Observational study
c. Cohort: prospective or retrospective
d. Case-control
e. Cross-sectional
f. Survey
g. Other

\section{Background/study aims:}

\section{Study objectives:}

6. Study population:
a. Inclusion criteria:
b. Exclusion criteria:
c. Sample size: Total:
d. Mean age $\pm \mathrm{SD}$ or CI:
Male:
Female:
e. Age groups:
f. Gender distribution: Male(\%):
Female(\%):
g. Control or comparison groups, if applicable: Yes No
h. SES Information available:
i. Race/ethnicity information
j. Other immunization/anti-viral hx information:

\section{Study setting:}


Study location: - Urban - Rural - Mixed

\section{Assessment of exposure:}

- Registry (is self-report included?) How is immunization status determined? - Method of validation?

\section{Assessment of outcome:}

How was timing of disease season determined?

How is VE calculated/defined?

How is VE measured?

\section{Study time period:}

\section{IIS Specifics:}

- What is specific role of IIS in this study?

- What type of data is contained in the immunization information system (IIS)?

- Is there an indication of accuracy?

- How is the registry system organized and maintained? Who funds this system?

- Was a reference data source used to assess the source population coverage?

- Is this a cross-sectional estimate, or conducted over a period of time?

o Is there a method of tracking immunization rates in order to compare annual rates?

- How is the registry tied into public health efforts?

- Other?

o Is there evidence of increased immunization/utilization among target populations?

o Address size of target and enrolled populations: high-risk groups, SES, race-

12. Results: ethnicity

Is a change in disease incidence reported?

Are figures reported for VE? If so, list them here:

\section{Study design characteristics:}

Types of bias addressed:

- Selection

- Detection

- Report

- Attrition

- Other

Residual confounding addressed?

Confounders:

a. Adjusted for potential confounders:
i. Yes
ii. No

b. List of confounders:

\section{Appropriate statistical analysis?}

\section{Limitations:}

16. Main findings:

\section{Other notes:}




\section{Appendix B. MODIFIED Downs and Black checklist}

\section{Reporting}

Total:

1. Is the hypothesis/aim/objective of the study clearly described?

\begin{tabular}{|l|l|}
\hline Yes & 1 \\
\hline No & 0 \\
\hline
\end{tabular}

2. Are the main outcomes to be measured clearly described in the Introduction or Methods section?

If the main outcomes are first mentioned in the Results section, the question should be answered no.

\begin{tabular}{|l|l|}
\hline Yes & 1 \\
\hline No & 0 \\
\hline
\end{tabular}

3. Are the characteristics of the patients included in the study clearly described? In cohort studies and trials, inclusion and/or exclusion criteria should be given. In case-control studies, a case-definition and the source for controls should be given.

\begin{tabular}{|l|l|}
\hline Yes & 1 \\
\hline No & 0 \\
\hline
\end{tabular}

4. Are the interventions of interest clearly described? Treatments and placebo (where relevant) that are to be compared should be clearly described.

\begin{tabular}{|l|l|}
\hline Yes & 1 \\
\hline No & 0 \\
\hline
\end{tabular}

5. Are the distributions of principal confounders in each group of subjects to be compared clearly described? A list of principal confounders is provided.

\begin{tabular}{|l|l|}
\hline Yes & 2 \\
\hline Partially & 1 \\
\hline No & 0 \\
\hline
\end{tabular}

6. Are the main findings of the study clearly described? Simple outcome data (including denominators and numerators) should be reported for all major findings so that the reader can check the major analyses and conclusions (This question does not cover statistical tests which are considered below).

\begin{tabular}{|l|l|}
\hline Yes & 1 \\
\hline No & 0 \\
\hline
\end{tabular}

7. Does the study provide estimates of the random variability in the data for the main outcomes? In non normally distributed data the inter-quartile range of results should be reported. In normally distributed data the standard error, standard deviation or confidence intervals should be reported. If the distribution of the data is not described, it must be 
assumed that the estimates used were appropriate and the question should be answered yes.

\begin{tabular}{|l|l|}
\hline Yes & 1 \\
\hline No & 0 \\
\hline
\end{tabular}

8. Have actual probability values been reported (e.g. 0.035 instead of 0.05 ) for the main outcomes except where the probability value is less than 0.001 ?

\begin{tabular}{|l|l|}
\hline Yes & 1 \\
\hline No & 0 \\
\hline
\end{tabular}

\section{External validity}

All the following criteria attempt to address the representativeness of the findings of the study and whether they may be generalized to the population from which the study subjects were derived.

9. Were the subjects ask ed to participate in the study representative of the entire population from which they were recruited? The study must identify the source population for patients and describe how the patients were selected. Patients would be representative if they comprised the entire source population, an unselected sample of consecutive patients, or a random sample. Random sampling is only feasible where a list of all members of the relevant population exists. Where a study does not report the proportion of the source population from which the patients are derived, the question should be answered as unable to determine.

\begin{tabular}{|l|l|}
\hline Yes & 1 \\
\hline No & 0 \\
\hline Unable to determine & 0 \\
\hline
\end{tabular}

10. Were the staff, places, and facilities where the patients were treated, representative of the treatment of the majority of patients receive? If yes, the study should demonstrate that the intervention was representative of that in use in the source population. The answer should be no if the intervention was undertaken in a specialist center unrepresentative of the hospitals most of the source population would attend.

\begin{tabular}{|l|l|}
\hline Yes & 1 \\
\hline No & 0 \\
\hline Unable to determine & 0 \\
\hline
\end{tabular}

Internal validity - bias

11. Were the statistical tests used to assess the main outcomes appropriate? The statistical techniques used must be appropriate to the data. For example nonparametric methods should be used for small sample sizes. Where little statistical analysis has been undertaken but where there is no evidence of bias, the question should be answered yes. If the distribution of the data (normal or not) is not described it must be assumed that the estimates used were appropriate and the question should be answered yes.

\begin{tabular}{|l|l|}
\hline Yes & 1 \\
\hline No & 0 \\
\hline Unable to determine & 0 \\
\hline
\end{tabular}

12. Were the main outcome measures used accurate (valid and reliable)? For studies where the outcome measures are clearly described, the question should be answered yes. For studies which refer to other work or that demonstrate the outcome measures are accurate, 
the question should be answered as yes.

\begin{tabular}{|l|l|}
\hline Yes & 1 \\
\hline No & 0 \\
\hline Unable to determine & 0 \\
\hline
\end{tabular}

\section{Was there adequate adjustment for confounding in the analyses from which the main}

findings were drawn? This question should be answered no for trials if: the main conclusions of the study were based on analyses of treatment rather than intention to treat; the distribution of known confounders in the different treatment groups was not described; or the distribution of known confounders differed between the treatment groups but was not taken into account in the analyses. In nonrandomized studies if the effect of the main confounders was not investigated or confounding was demonstrated but no adjustment was made in the final analyses the question should be answered as no.

\begin{tabular}{|l|l|}
\hline Yes & 1 \\
\hline No & 0 \\
\hline Unable to determine & 0 \\
\hline & \\
\hline
\end{tabular}

\section{References}

[1] Roush S, Murphy T. Historical comparisons of morbidity and mortality for vaccine-preventable diseases in the United States. JAMA 2007;298(18):2155-63.

[2] Zhou F, Santoli J, Messonnier M, Yusuf H, Shefer A, Chu S, et al. Economic evaluation of the 7 -vaccine routine childhood immunization schedule in the United States, 2001. Arch Pediatr Adolesc Med 2005;159(12):113644.

[3] Weinberg G, Szilagyi P. Vaccine epidemiology: efficacy, effectiveness, and the translational research roadmap. J Infect Dis 2010;201(11):1607-10.

[4] Ruiz-Palacios G, Prez-Schael I, Velzquez FR, Abate H, Breuer T, Clemens S, et al. Safety and efficacy of an attenuated vaccine against severe rotavirus gastroenteritis. N Engl J Med 2006;354(1):11-22.

[5] Broome CV, Facklam RR, Fraser DW. Pneumococcal disease after pneumococcal vaccination: an alternative method to estimate the efficacy of pneumococcal vaccine. N Engl J Med 1980;303(10):549-52.

[6] Averhoff F, Shapiro CN, Bell BP, Hyams I, Burd L, Deladisma A, et al. Control of hepatitis A through routine vaccination of children. JAMA 2001;286(23): 2968.

[7] Orenstein WA, Bernier RH, Hinman AR. Assessing vaccine efficacy in the field. Further observations. Epidemiol Rev 1988;10:212.

[8] Adamkiewicz T, Silk B, Howgate J, Baughman W, Strayhorn G, Sullivan K, et al. Effectiveness of the 7-valent pneumococcal conjugate vaccine in children with sickle cell disease in the first decade of life. Pediatrics 2008;121(3):562.

[9] Rodewald L, Maes E, Stevenson J, Lyons B, Stokley S, Szilagyi P. Immunization performance measurement in a changing immunization environment. Pediatrics 1999;103(4):889.

[10] Development of community- and state-based immunization registries. CDC response to a report from the national vaccine advisory committee. Morb Mortal Wkly Rep Recomm Rep 2001;50(RR-17):1.

[11] Linkins R, Salmon D, Omer S, Pan W, Stokley S, Halsey N. Support for immunization registries among parents of vaccinated and unvaccinated school-aged children: a case control study. BMC Public Health 2006;6:236.

[12] Immunization information systems progress - United States, 2006. MMWRMorb Mortal Wkly Rep 2008;57(11):289.

[13] Stille C, Christison-Lagay J. Determining immunization rates for inner-city infants: statewide registry data vs medical record review. Am J Public Health 2000;90(October (10)):1613-5.

[14] Kempe A, Beaty BL, Steiner JF, Pearson KA, Lowery NE, Daley MF, et al. The regional immunization registry as a public health tool for improving clinical practice and guiding immunization delivery policy. Am J Public Health 2004;94(June (6)):967-72.

[15] Zimmerman L, Bartlett D, Enger K, Gosney K, Williams W. Influenza vaccination coverage: findings from immunization information systems. BMC Pediatr 2007;7:28.

[16] Piedra P, Gaglani M, Kozinetz C, Herschler G, Fewlass C, Harvey D, et al. Trivalent live attenuated intranasal influenza vaccine administered during the 2003-2004 influenza type A (H3N2) outbreak provided immediate, direct, and indirect protection in children. Pediatrics 2007;120(3):e553.

[17] Allison M, Daley M, Crane L, Barrow J, Beaty B, Allred N, et al. Influenza vaccine effectiveness in healthy 6- to 21-month-old children during the 2003-2004 season. J Pediatr 2006;149(6):755.

[18] Tate J, Curns A, Cortese M, Weintraub E, Hambidge S, Zangwill K, et al. Burden of acute gastroenteritis hospitalizations and emergency department visits in US children that is potentially preventable by rotavirus vaccination: a probe study using the now-withdrawn rotashield vaccine. Pediatrics 2009;123(3): 744.

[19] Torvaldsen S, Simpson J, McIntyre P. Effectiveness of pertussis vaccination in New South Wales, Australia, 1996-1998. Eur J Epidemiol 2003;18(1):63.
[20] Mahon B, Shea K, Dougherty N, Loughlin A. Implications for registry-based vaccine effectiveness studies from an evaluation of an immunization registry: a cross-sectional study. BMC Public Health 2008;8:160.

[21] Wood, Saarlas, Inkelas, Matyas. Immunization registries in the United States: implications for the practice of public health in a changing health care system. Annu Rev Public Health 1999;20:231.

[22] Blumenthal D, Tavenner M. The "meaningful use" regulation for electronic health records. N Engl J Med 2010;363(6):501-4.

[23] Klein K. So much to do, so little time. To accomplish the mandatory initiatives of ARRA, healthcare organizations will require significant and thoughtful planning, prioritization and execution. J Healthc Inf Manage 2010;24(1):31.

[24] Saarlas K, Hinman A, Ross D, Watson W, Wild E, Hastings T, et al. All kids count 1991-2004: developing information systems to improve child health and the delivery of immunizations and preventive services. J Public Health Manage Pract 2004;(Suppl.):S3.

[25] Groom H. Immunization information systems: an update. In: Presented at: National immunization conference. 2009.

[26] Allison M, Daley M, Barrow J, Crane L, Beaty B, Allred N, et al. High influenza vaccination coverage in children with high-risk conditions during a vaccine shortage. Arch Pediatr Adolesc Med 2009;163(5):426.

[27] Irving S, Donahue J, Shay D, Ellis-Coyle T, Belongia E. Evaluation of self-reported and registry-based influenza vaccination status in a Wisconsin cohort. Vaccine 2009;27(47):6546.

[28] Greene S, Shi P, Dutta-Linn MM, Shoup J, Hinrichsen V, Ray P, et al. Accuracy of data on influenza vaccination status at four Vaccine Safety Datalink sites. Am J Prev Med 2009;37(6):552.

[29] Downs SH, Black N. The feasibility of creating a checklist for the assessment of the methodological quality both of randomised and non-randomised studies of health care interventions. J Epidemiol Community Health 1998;52(6):377.

[30] From the Centers for Disease Control and Prevention. Measles outbreak Netherlands, April 1999-January 2000. JAMA 2000;283(18):2385.

[31] Fu C, Nie J, Liang J, Wang M. Evaluation of live attenuated S79 mumps vaccine effectiveness in mumps outbreaks: a matched case-control study. Chin Med J 2009;122(3):307.

[32] Hviid A, Stellfeld M, Andersen P, Wohlfahrt J, Melbye M. Impact of routine vaccination with a pertussis toxoid vaccine in Denmark. Vaccine 2004;22(27-28):3530.

[33] Ortqvist A, Granath F, Askling J, Hedlund J. Influenza vaccination and mortality: prospective cohort study of the elderly in a large geographical area. Eur Respir J 2007;30(3):414.

[34] Galloway Y, Stehr-Green P, McNicholas A, O'Hallahan J. Use of an observational cohort study to estimate the effectiveness of the New Zealand group B meningococcal vaccine in children aged under 5 years. In J Epidemiol 2009;38(2): 413.

[35] Fu C, Liang J, Wang M. Matched case-control study of effectiveness of live, attenuated S79 mumps virus vaccine against clinical mumps. Clin Vacc Immunol 2008;15(9):1425.

[36] Markey P, Krause V, Boslego JW, Coplan PM, Dargan JM, Kaplan KM. The effectiveness of haemophilus influenzae type b conjugate vaccines in a highrisk population measured using immunization register data. Epidemiol Infect 2001;126(1):31.

[37] Bialek SR, Helgenberger L, Fischer GE, Bower WA, Konelios M, Chaine JP, et al. Impact of routine hepatitis $B$ immunization on the prevalence of chronic hepatitis B virus infection in the Marshall Islands and the Federated States of Micronesia. Pediatr Infect Dis J 2010;29(1):18-22.

[38] Hviid A, Melbye M. Impact of routine vaccination with a conjugate haemophilus influenzae type b vaccine. Vaccine 2004;22(3-4):378.

[39] van Alphen L, Spanjaard L, van der Ende A, Schuurman I, Dankert J. Effect of nationwide vaccination of 3-month-old infants in the Netherlands with con- 
jugate haemophilus influenzae type b vaccine: high efficacy and lack of herd immunity. J Pediatr 1997;131(6):869.

[40] Kelly C, Arnold R, Galloway Y, O'Hallahan J. A prospective study of the effectiveness of the New Zealand meningococcal B vaccine. Am J Epidemiol 2007;166(7):817.

[41] Barricarte A, Castilla J, Gil-Setas A, Torroba L, Navarro-Alonso J, Irisarri $\mathrm{F}$, et al. Effectiveness of the 7-valent pneumococcal conjugate vaccine: a population-based case-control study. Clin Infect Dis 2007;44(11): 1436.
[42] Boom J, Tate J, Sahni L, Rench M, Hull J, Gentsch J, et al. Effectiveness of pentavalent rotavirus vaccine in a large urban population in the United States. Pediatrics 2010;125(2):e199-207.

[43] Why collect individual-level vaccination data? ECMAJ Can Med Assoc J 2010;182(3):273-5.

[44] Kolasa M, Chilkatowsky A, Clarke K, Lutz J. How complete are immunization registries? The Philadelphia story. Ambul Pediatr 2006;6(1):21.

[45] Boyd T, Linkins R, Mason K, Bulim I, Lemke B. Assessing immunization registry data completeness in Bexar County, Texas. Am J Prev Med 2002;22(3):184. 